\title{
Conventional Water Treatment of Domestic Groundwater Supplies
}

\author{
Hussein Hamid Emran Al-Husseini \\ Department of Environmental Engineering, College of Engineering, University of Babylon, \\ Babylon, Iraq \\ Husseini73@yahoo.com
}

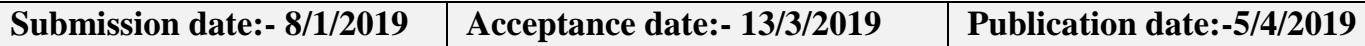

\begin{abstract}
The important of ground water is increasing in the future as a source of fresh waters; in addition, many countries contain a number of water treatment plants to treat surface water. Using conventional treatment plant in the cities to treat ground water will decrease the cost of ground water treatment and may be help to depend on both surface and ground water supplies. This paper studied the ability of treating ground water by conventional water treatment. The quality of the ground water source is studied in the mention area during study period. The chemical quality of ground water is tested and there is within the standards of drinking water except iron. The conventional treatment was enhancing quality of treated water by increment of dissolved oxygen concentrations toward optimum value. Water treatment plant was effective for removal of iron from ground water of about $50 \%$, in addition there is an effect of conventional treatment on sulfate removal (sulfate may be increase above standards in some ground water sources). The statistical analysis of data shows there is a correlation between quality parameters of raw and treated water and between iron and sulfate of treated water in the correlation matrix. In addition, confidence test was applied on the correlation coefficients using fisher's transformation. The analysis shows, that there is a positive period $(0.244,0.941)$ of confidence of $95 \%$ of correlation factors of iron and sulfate.
\end{abstract}

Key words: Water quality, Ground water, Conventional treatment, Statistical analysis.

\section{1- Introduction}

Ground water refers to the water that take over the soil voids and cracks within geological formations which originated from atmospheric precipitation the sources of ground water reservoir from rain fall infiltration or form surface water [1].

The ground water represent about $94 \%$ of refresh water can be using [2].Ground water begins as precipitation, which falls on the land surface and slowly seeps downward in to the ground. Before reaching the ground the rain contacts with bacteria, suspended solids, and dissolved solids and gases [3].

Water is drawn from the ground for different uses, basically for domestic, agricultural, and industrial uses .Unlike ground water may be used for other purposes such as recreation and fisheries [4].The domestic use of ground water represents an important water supply for human uses. As was mentioned above, the moving of ground water through soil makes picked up solids (dissolved and suspended) and bacteria and cause pollution of ground water.

The pollutants of ground water include physical, chemical and bacteriological substances [3]. Physical chemical quality used to define the characteristics of water which may affect its acceptability due to aesthetic considerations [5]. 


\section{2- Water treatment}

The aim of water treatment process is to enhancing quality of raw water to be suitable for domestic purposes [6]. The conventional water treatment process for treatment of raw water includes rapid mixing, flocculation, coagulation, filtration and disinfection [7]. The conventional treatment of water is applied usually for treatment of surface raw water and it was evaluated [8].

In general, groundwater is widely used for irrigation, industrial activities, drinking, and domestic purposes. The water quality in both surface and ground water resources was negatively affected. Therefore, study the quality of other sources of water in the urban area such as groundwater is of prime importance [9].

In many countries, ground water is the main important source for drinking water. In Iraq the ground water is used for different purposes in many regions that the surface water not available (quantity or quality).

Because of high percent of ground water of fresh water it is may be the main source for domestic use in the recent an future ,therefore conventional treatment may be used for low operation cost to satisfy standards.

The aim of the present paper is to study the effect of conventional treatment to enhance the quality of ground water as a source for domestic use.

\section{3- Study water treatment plant}

Conventional treatment of ground water was studied for this purpose; small water treatment plant depends on ground water as water supply. The conventional treatment process includes rapid mixing, coagulation, sedimentation, filtration and disinfection. The location of the study was conducted in the region of Barak Al-Shatee in the African desert. The population of this region depends on ground water wells as a source of drinking water. The local government based on conventional treatment plant to treat ground water. This information were taken from the water treatment plant reference.

\section{3-1 Source of raw water}

The well of raw water represents the main source. It is near the water treatment plant and has a depth of $110 \mathrm{~m}$ and the water was drawn by a pump of (65-180) cubic meter per hour. The water treatment processes consist of the following:

\section{3-2 Coagulation and flocculation process}

\section{3-2-1 Coagulation}

Coagulation of raw water concludes using a tank of retention time equal to 2 min using aluminum sulfate as coagulant. After coagulation process flocculation was applied to water for about $15 \mathrm{~min}$ to complete the first process.

\section{3-2-2 Flocculation}

The chemical additions were injection to water through three cylindrical tanks each 500 liter with their accessories, first contains aluminum sulfate, the second contains low speed paddles to make dense liquid that sediment in the tank.

\section{3-2-3 Sedimentation}

Sedimentation process was applied through trays method, which is effective to increase the surface area of sedimentation. Water passes after trays units to conic boxes unit by controlling weir to complete sedimentation process. The total quantity of water was controlling by floating valve. This valve is controlling water quantity flow to the next process (filters) according to the head loss.

\section{3-2-4 Filtration}


The filtration process consists of pressure filter with $1200 \mathrm{~mm}$ in height pressure filter is one type of filtration process in conventional water treatment plant [10]. The plant contains three pressure filters.

\section{4- Experimental work}

The positions of water sampling are shown in the figure (1) five points of sampling were selected to test water through treatment units. The raw and treated water samples in position (1) and (5) were tested during study period for eleven weeks, the tests include, total hardness, bicarbonate, chloride, sodium, magnesium, coliseum, potassium, iron, sulfate and sodium chloride. The determination of water quality parameters (raw and treated) is based on titration methods in environmental chemistry except for electrical conductivity, iron , where electrical conductivity was measured using Hydro lab Quanta W.Q.M and the value of iron concentrations were measured using Atomic Absorption Spectro Photometer) apparatuses. In addition, samples of water through treatment processes were drawn position (2), (3) and (4) to evaluation the efficiency of removal of total solids (using electrical conductivity value) and additional of dissolved oxygen in sedimentation and filtration tanks. All experimental tests were conducted according to the world health organization standards [5].

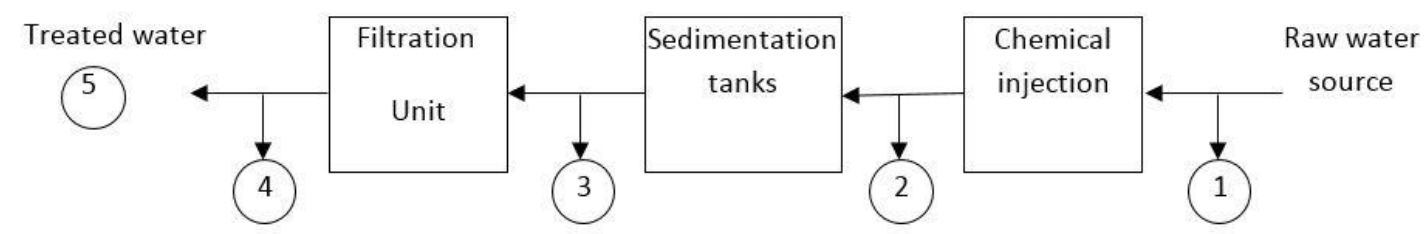

Fig. (1) Locations of water sampling (water treatment plant ref.)

\section{5- Discussion}

The effect of treatment units and processes on the quality of ground water may be studied in two directions the one is all units of treatment, the other effect of each unit of the water treatment plant.

The concentrations of chemical parameters of treated water are within global and local standard that are shown in table (1), except iron. The concentration of iron exceeds the allowable values of global and local standards (equal to $4.0 \mathrm{mg} / \mathrm{l}$ ) as shown in figure (11).

\section{Table (1) Global and local water quality standards}

\begin{tabular}{|l|c|c|c|c|c|}
\hline \multirow{2}{*}{ property } & \multirow{2}{*}{ unit } & \multicolumn{2}{c|}{ Global standard } & \multicolumn{2}{c|}{ Local standard } \\
\cline { 3 - 6 } & & $\begin{array}{c}\text { Perfect } \\
\text { con. }\end{array}$ & $\begin{array}{c}\text { Allowable } \\
\text { con. }\end{array}$ & $\begin{array}{c}\text { Perfect } \\
\text { con. }\end{array}$ & Allowable con. \\
\hline $\begin{array}{l}\text { Electrical } \\
\text { conductivity }\end{array}$ & $\mu \mathrm{m} / \mathrm{cm}$ & - & 0.0004 & - & - \\
\hline T. hardness & $\mathrm{Mg} / \mathrm{l}$ & & 500 & 200 & 500 \\
\hline Sodium & $\mathrm{Mg} / \mathrm{l}$ & 20 & 175 & 20 & 200 \\
\hline Calcium & $\mathrm{Mg} / \mathrm{l}$ & 100 & 200 & 75 & 200 \\
\hline Magnesium & $\mathrm{Mg} / \mathrm{l}$ & 30 & 150 & 30 & 150 \\
\hline Chloride & $\mathrm{Mg} / \mathrm{l}$ & 25 & 200 & 200 & 250 \\
\hline Sulfate & $\mathrm{Mg} / \mathrm{l}$ & 25 & 250 & 200 & 400 \\
\hline Iron & $\mathrm{Mg} / \mathrm{l}$ & 0.02 & 0.05 & 0.1 & 0.3 \\
\hline
\end{tabular}

The variation of ground water parameters through treatment plant are shown in the next discussion. Figures (2), (5),(6),(8),(9)and (10) show that the concentration of most treated water parameters increase with equivalent of raw water there is low effect of water treatment units in the removal of these parameters.

Water treatment plant effects on the concentrations of some water parameters, which are chlorides, sodium chloride and magnesium. The water treatment removes chlorides with percent of $15 \%$, figure (3). In addition, water it removes sodium chloride with a percent of $17 \%$, figure (4). Water treatment plant also remove magnesium with percent of $10 \%$, figure (7) .The process of removal of 
these chemical elements may be mainly to the chemical and physical properties of sedimentation and filter units.

The effect of water treatment plant is clear on sulfate and iron. The iron in ground water is common parameter with concentrations exceed the proper limits of drinking water standards. The water treatment removes iron from water with percent of 50\% as shown in the figure (11).The removal of iron from ground water represents important result since the presence of iron in drinking water causes many problems like tasting and coloring of plumbing. The conventional treatment is sufficient for iron removal. The treatment plant removes sulfate from ground water with percentage of about $50 \%$.

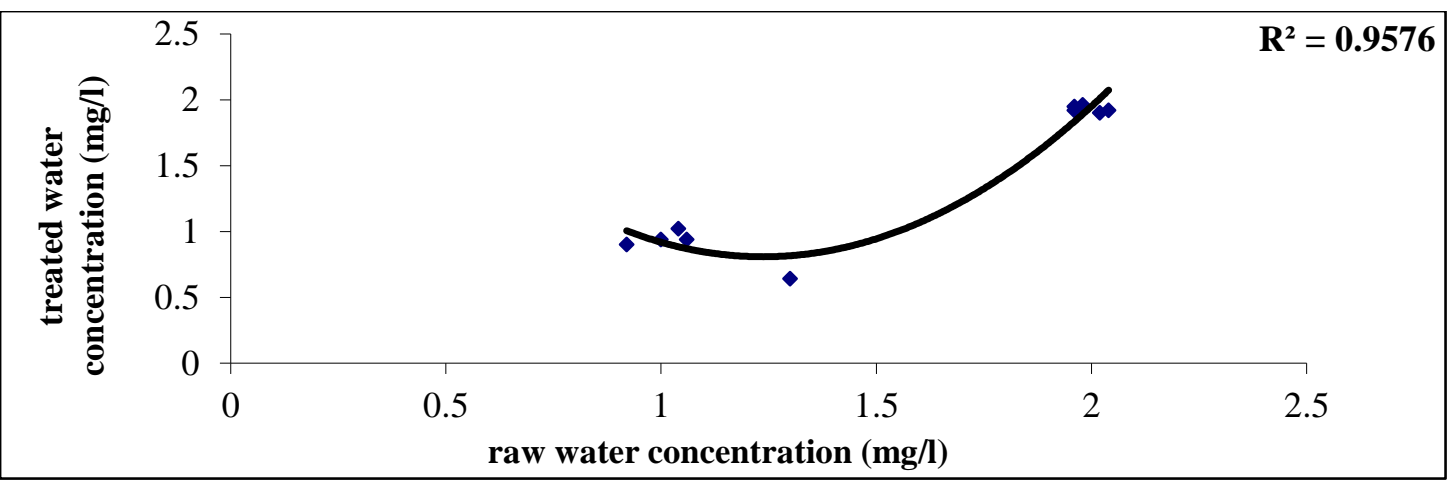

Fig. (2) Relation of raw and treated water bicarbonates concentrations

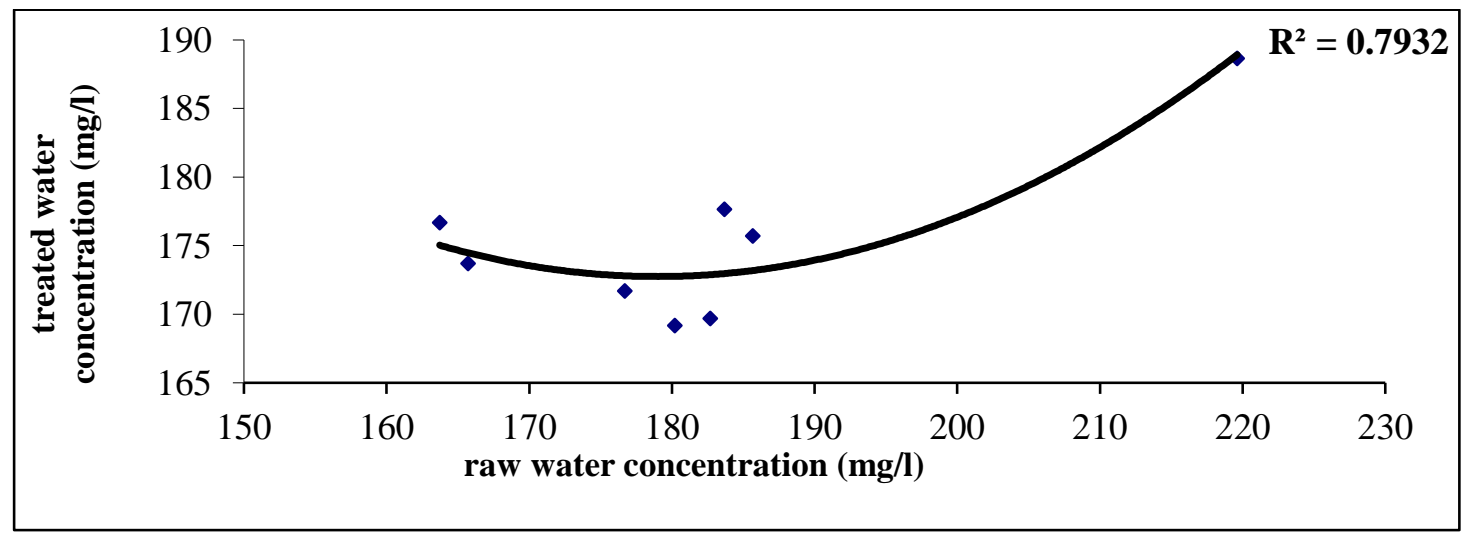

Fig. (3) Relation of raw and treated water chlorides concentration (mg/l)

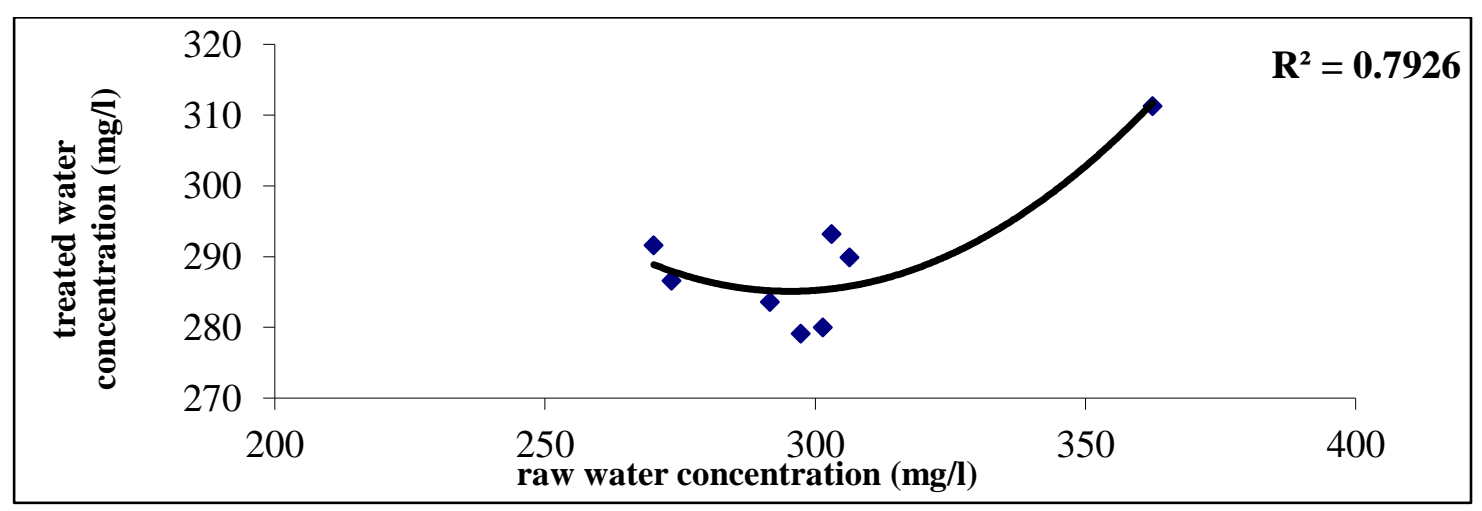

Fig. (4) Relation of raw and treated water sodium chloride concentration (mg/l) 


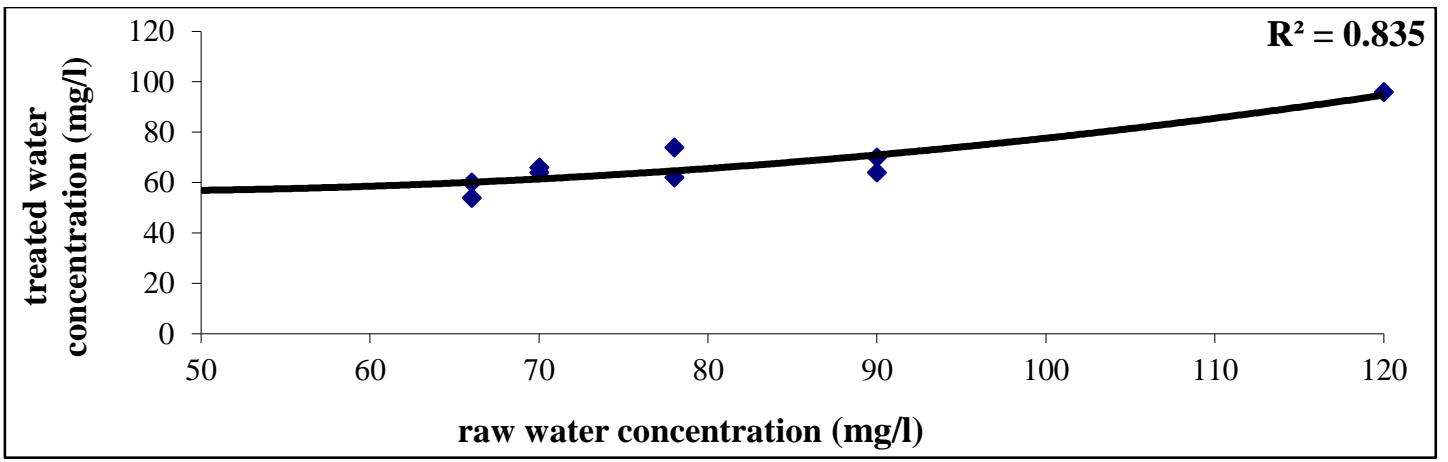

Fig. (5) Relation of raw and treated water hardness concentration (mg/l)

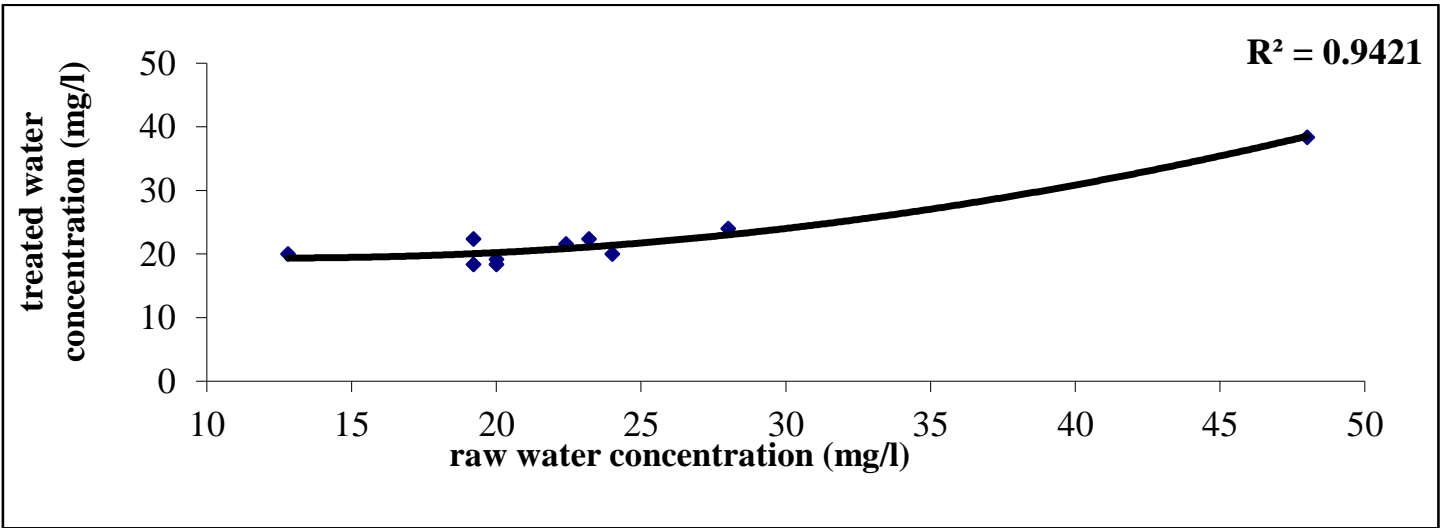

Fig. (6) Relation of raw and treated water calcium concentration (mg/l)

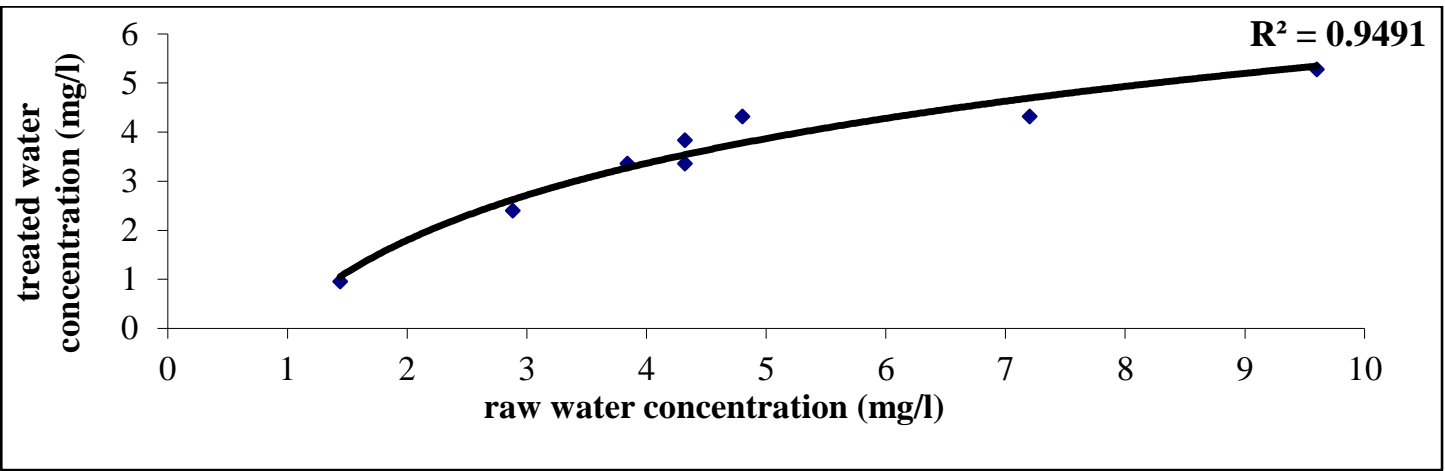

Fig. (7) Relation of raw and treated water magnesium concentration (mg/l)

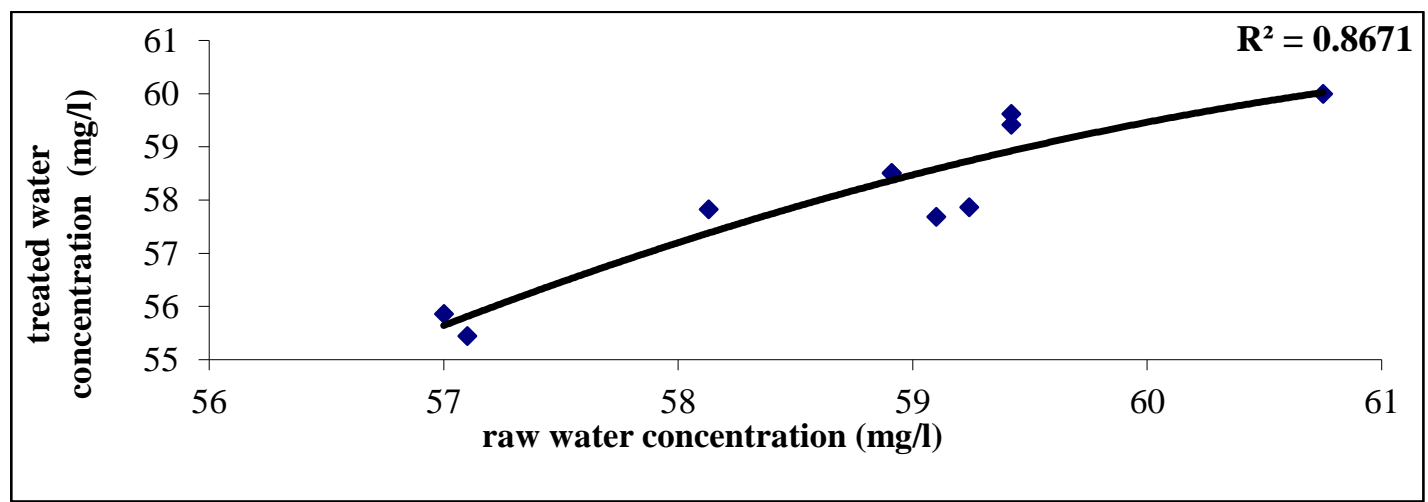

Fig. (8) Relation of raw and treated water sodium concentration (mg/l) 


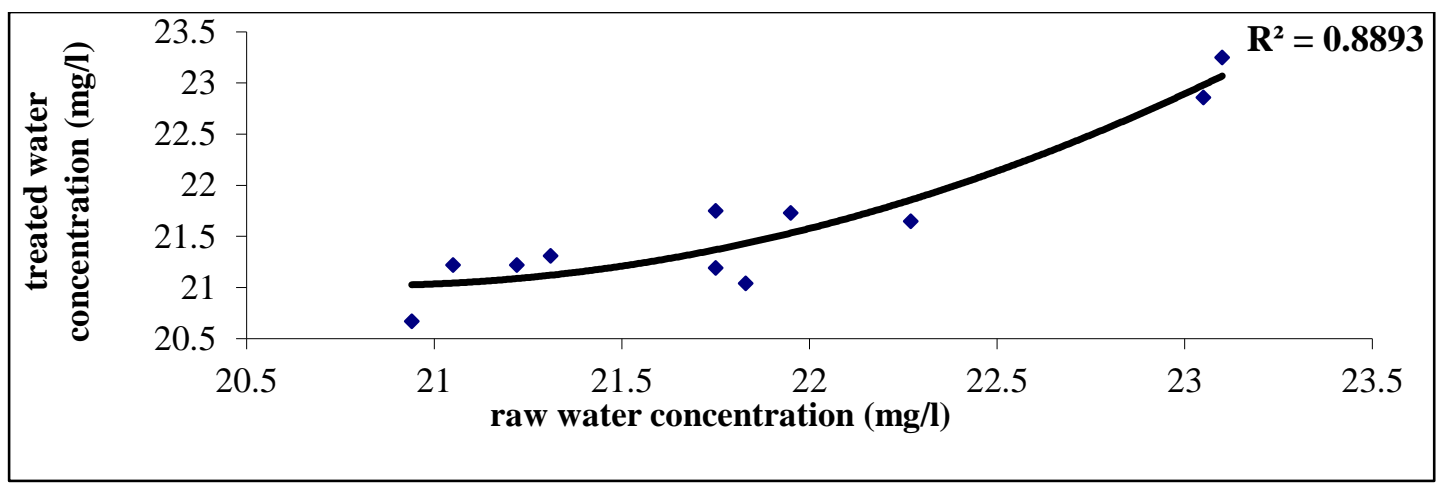

Fig. (9) Relation of raw and treated water potassium concentration $(\mathrm{mg} / \mathrm{l})$

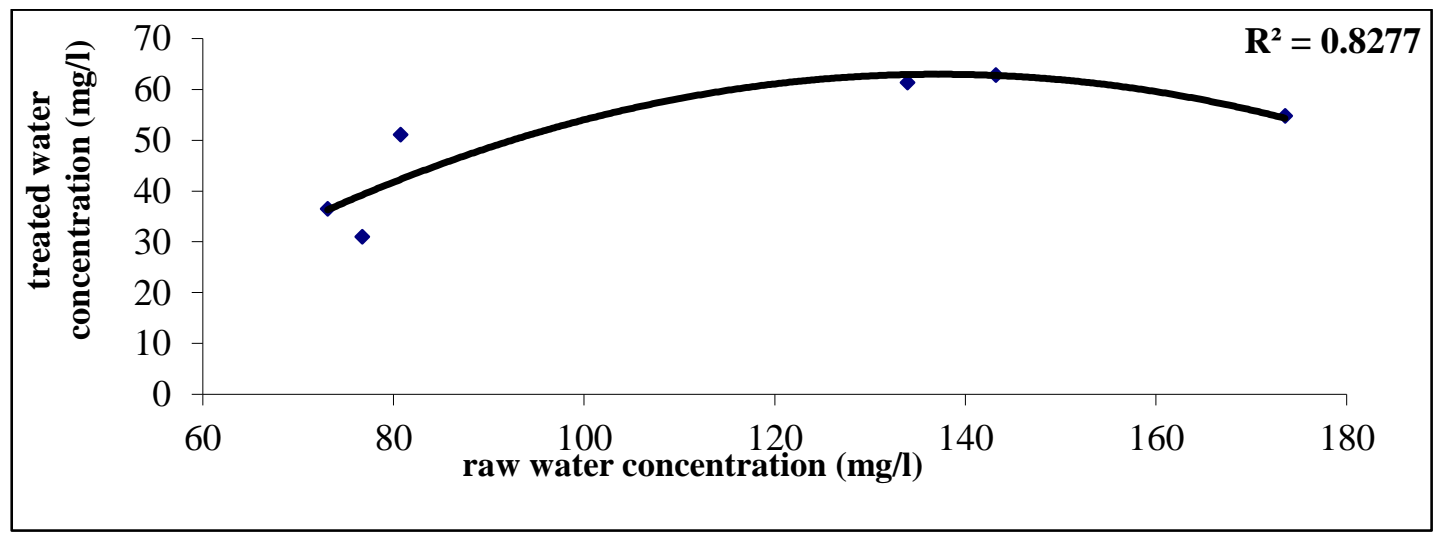

Fig. (10) Relation of raw and treated water sulfate concentration (mg/l)

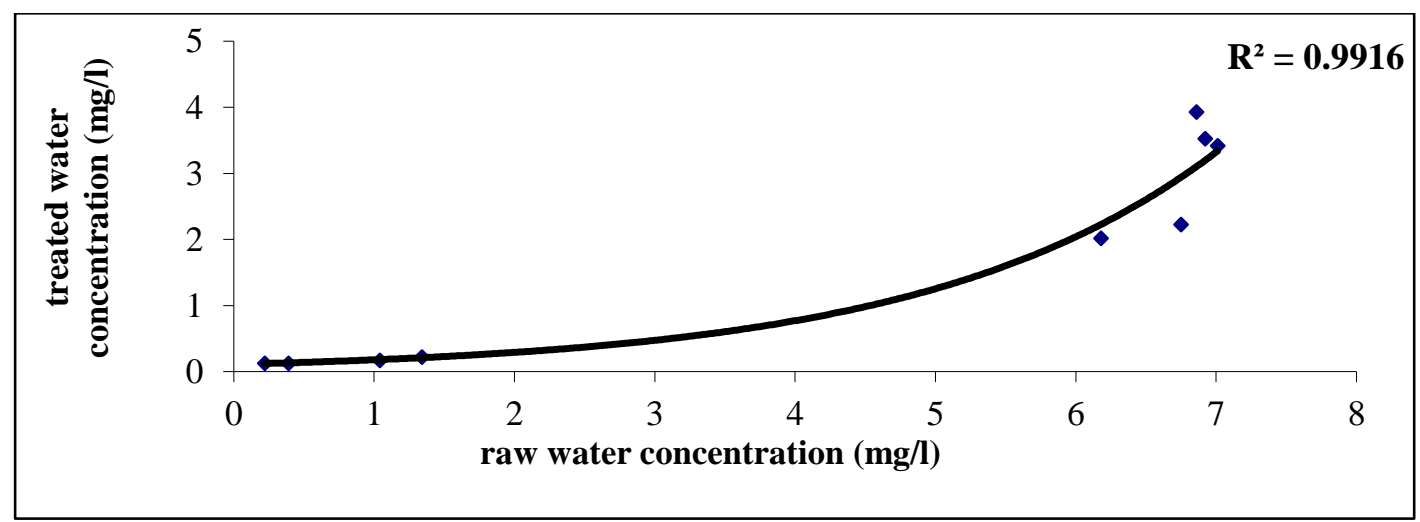

Fig. (11) Relation of raw and treated water iron concentration (mg/l)

To evaluation the individual unit process and unites in the parameter removal sedimentation tank and filter were selected as the main parts of the conventional water treatment plant .In addition electrical conductivity and dissolved oxygen as general indicator for this. Electrical conductivity used as indicator for total solids .for sedimentation tank the percentage of reduction of conductivity is shown in figure (12). The trend of the relation represents increasing of removal with increasing of total solids flow to sedimentation tank. In the filtration process, figure (13) we may show that with increasing the total solids the percentage decrease this may be to more solids that inter to the filter and this above the capacity of filter media and cause increasing in the effluent total solids in the case of high influent total solids.

Dissolved oxygen is needed to solute of organic matter that found in the water. Both sedimentation and filtration increase dissolved oxygen above the influent concentration of about $10 \%$ and $15 \%$, as shown in the figures, (14) and (15) respectively. This is a result of water eddy in sedimentation tank and to moving of water through pores of filter media. 


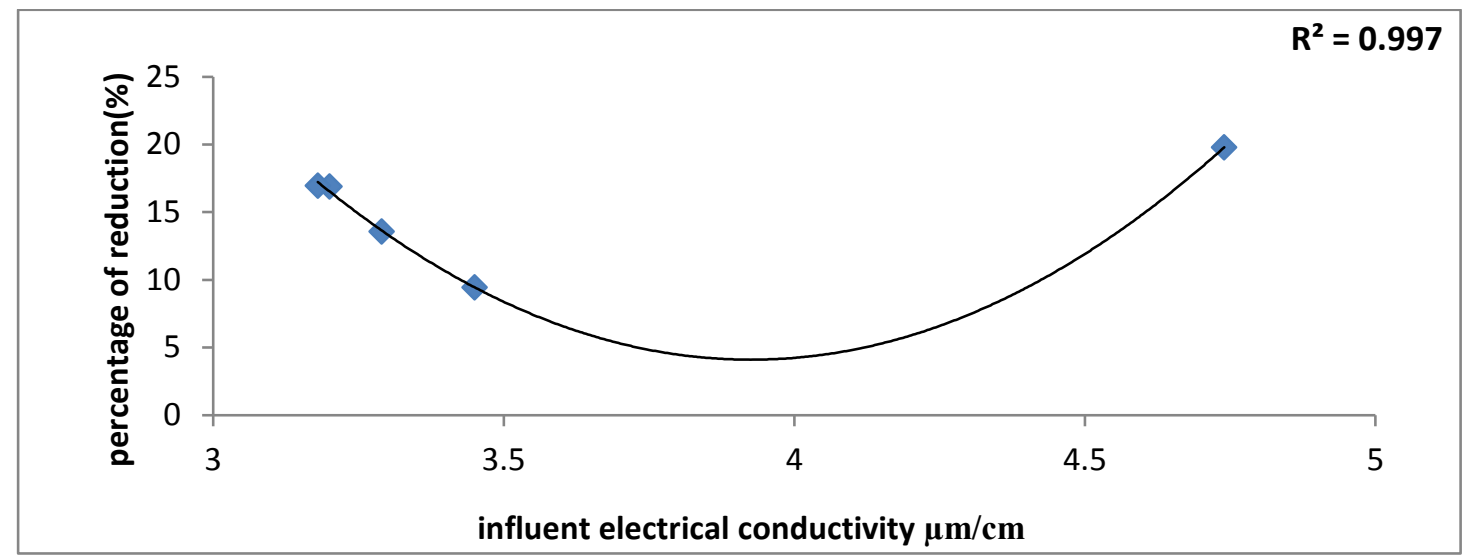

Fig. (12) Relation of electrical conductivity $(\mathrm{mm} / \mathrm{cm})$ and percent of reduction for sedimentation tank

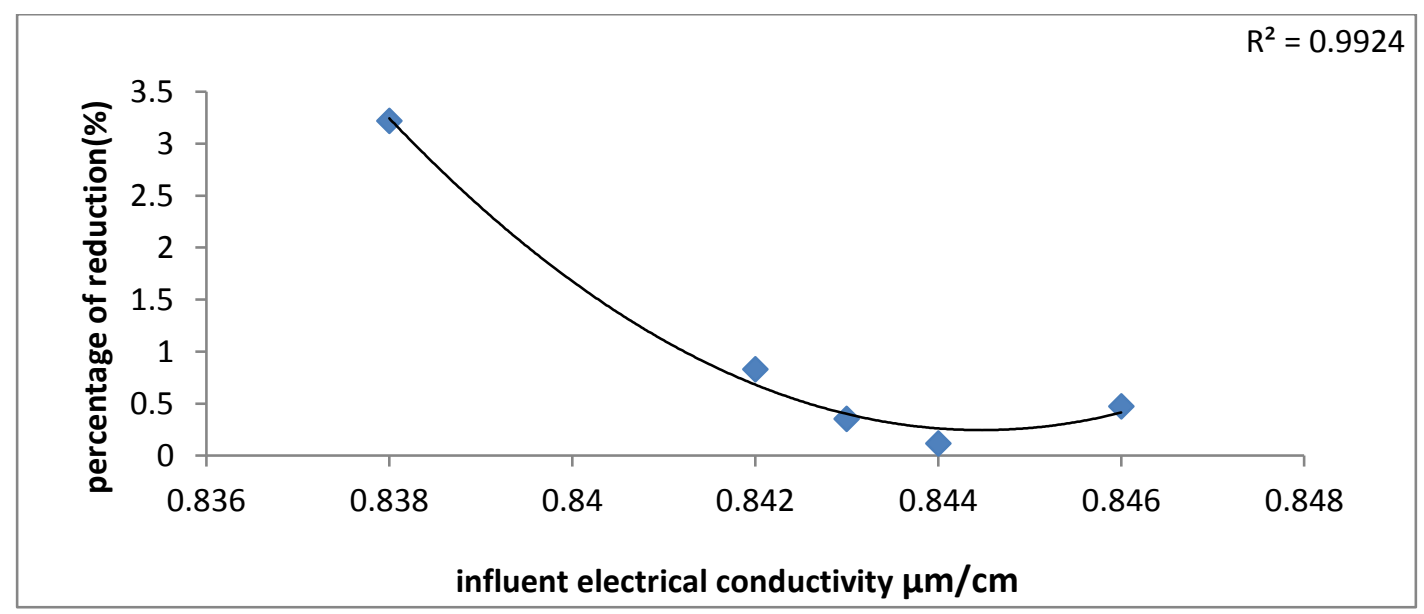

Fig. (13) Relation of electrical conductivity $(\mathrm{mm} / \mathrm{cm})$ and percent of reduction for filter

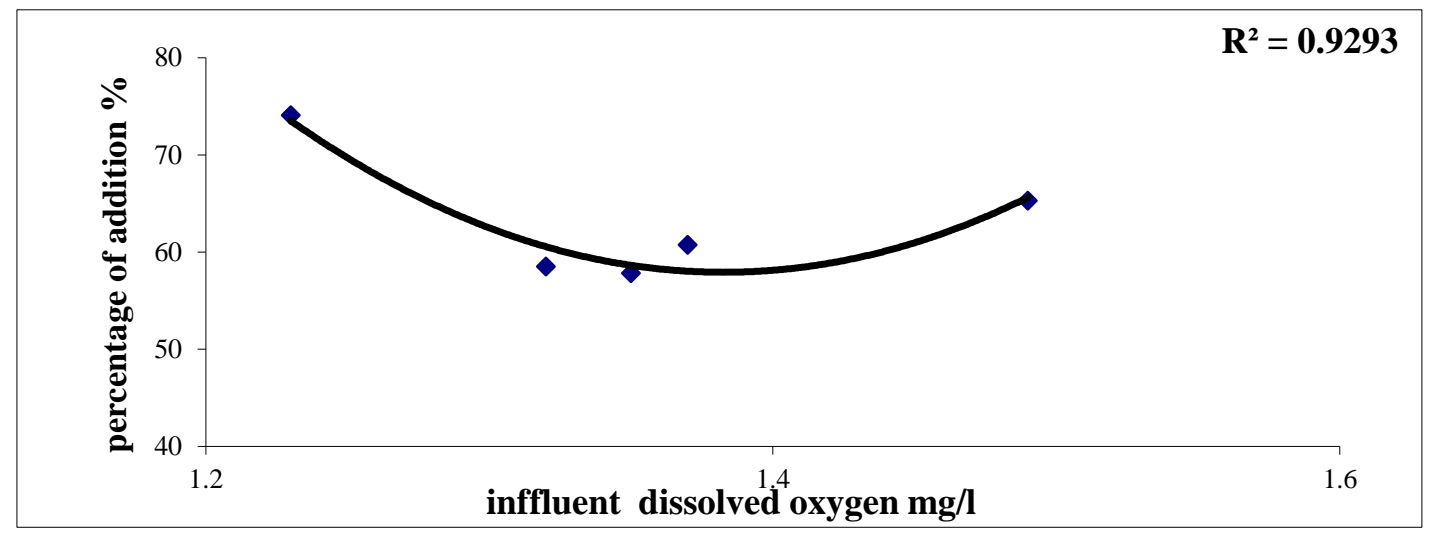

Fig. (14) Relation of dissolved oxygen concentration (mg/l) and percent of addition for sedimentation tank 


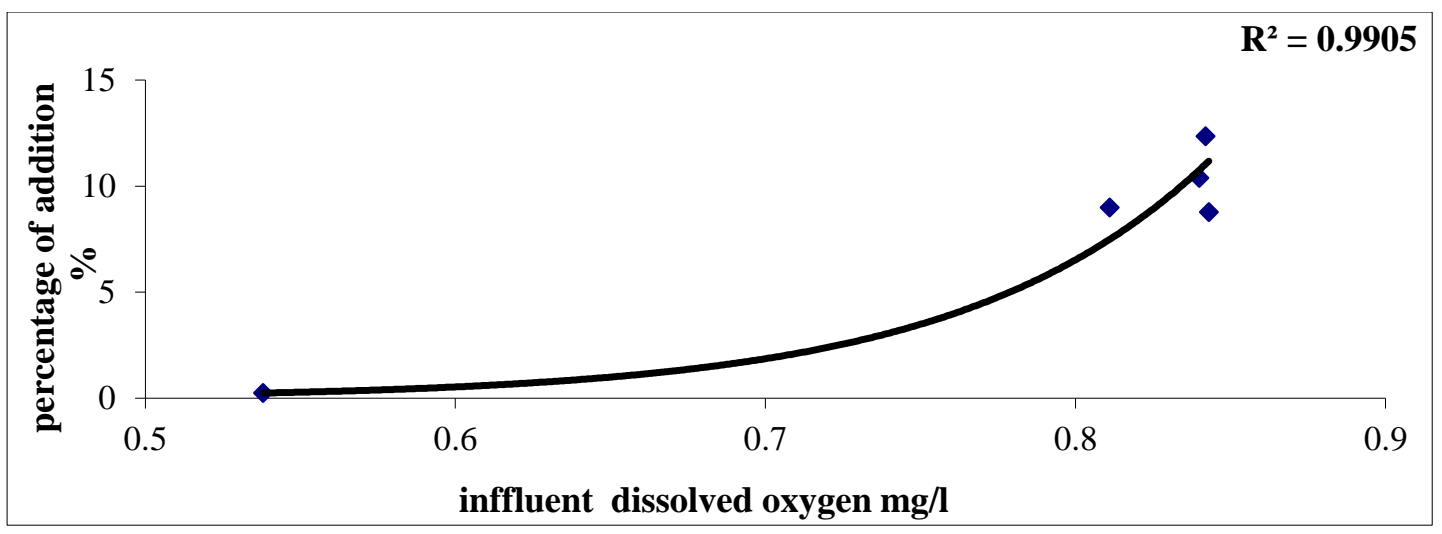

Fig. (15) Relation of dissolved oxygen concentration ( $\mathrm{mg} / \mathrm{l})$ and percent of addition for filter

Statistical analysis was applied to data of raw and treated water quality parameters to find correlation coefficient between raw and treated water factors. . As shown in table (1). The quality parameters have high correlation of influent and effluent water quality components.

Table (1) Correlation Coefficient of Raw-Treated Water Parameters

\begin{tabular}{|c|c|c|c|c|c|c|c|c|c|c|}
\hline 离 & 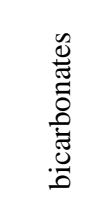 & $\begin{array}{l}\frac{0}{0} \\
\frac{0}{J}\end{array}$ & 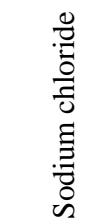 & 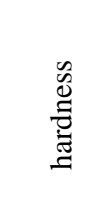 & $\begin{array}{l}\text { 竞 } \\
\frac{0}{\tilde{J}}\end{array}$ & 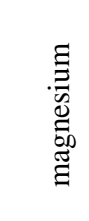 & 䒠 & 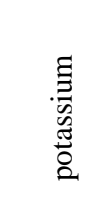 & 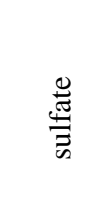 & : \\
\hline 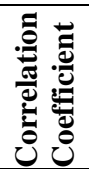 & 0.980 & 0.890 & 0.890 & 0.910 & 0.970 & 0.970 & 0.930 & 0.940 & 0.910 & 0.960 \\
\hline
\end{tabular}

The relation between different water parameters was founded by correlation factor using the SPSS statistics program .Table (2) shows correlation factors of treated water , as shown in the table there is a positive correlation between iron and sulfate ions concentrations and equal about to 0.800 , this may be to the removal in the treatment processes of water treatment plant .The ' units remove iron and sulfate compound from ground raw water as shown previous, from this it may conclude that there is a relation between the two components in concentration and removal through treatment process. 
Table (2) Pearson Correlation Coefficients of Treated Water

\begin{tabular}{|c|c|c|c|c|c|c|c|c|c|c|}
\hline & HCO3 & $\mathbf{C a}$ & $\mathbf{C l}$ & $\mathbf{F e}$ & $\mathbf{T . ~ H a r .}$ & $\mathbf{K}$ & $\mathbf{M g}$ & $\mathbf{N a}$ & $\mathbf{N a C l}$ & $\mathbf{S O}_{4}$ \\
\hline $\mathbf{H C O 3}$ & 1.000 & 0.229 & -0.412 & -0.389 & 0.434 & -0.062 & 0.543 & 0.117 & -0.410 & -0.784 \\
\hline $\mathbf{C a}$ & 0.229 & 1.000 & -0.244 & -0.350 & 0.870 & 0.011 & 0.085 & 0.531 & 0.244 & -0.393 \\
\hline $\mathbf{C l}$ & -0.412 & -0.244 & 1.000 & 0.461 & 0.214 & 0.081 & -0.181 & 0.405 & 1.000 & 0.566 \\
\hline $\mathbf{F e}$ & -0.389 & -0.350 & 0.461 & 1.000 & -0.215 & -0.285 & 0.095 & 0.369 & 0.465 & 0.756 \\
\hline $\mathbf{T . ~ H a r .}$ & 0.434 & 0.870 & 0.214 & -0.215 & 1.000 & 0.144 & 0.539 & 0.704 & 0.216 & -0.371 \\
\hline $\mathbf{K}$ & -0.062 & 0.011 & 0.081 & -0.285 & 0.144 & 1.000 & 0.114 & 0.129 & 0.081 & 0.111 \\
\hline $\mathbf{M g}$ & 0.543 & 0.085 & -0.181 & 0.095 & 0.539 & 0.114 & 1.000 & 0.488 & -0.177 & -0.212 \\
\hline $\mathbf{N a}$ & 0.117 & 0.531 & 0.405 & 0.369 & 0.704 & 0.129 & 0.488 & 1.000 & 0.410 & 0.106 \\
\hline $\mathbf{N a C l}$ & -0.410 & 0.244 & 1.000 & 0.465 & 0.216 & 0.081 & -0.177 & 0.410 & 1.000 & 0.566 \\
\hline $\mathbf{S O}$ & -0.784 & -0.393 & 0.566 & 0.756 & -0.371 & 0.111 & -0.212 & 0.106 & 0.566 & 1.000 \\
\hline
\end{tabular}

Confidence intervals around Pearson's are not symmetrical and the confidence interval around a Pearson $r$ is based on Fisher's r-to-z transformation [11]. The correlation coefficient is not normally distributed and its variance is not constant [12].

The testing of confidence of correlation factors is shown in the table (3). The confidence test was applied with an interval of $95 \%$, to test the correlation between treated water parameters. The confidence interval of sulfate and iron correlation is positive ends $(0.244,0.941)$, this refers to the high correlation between these groundwater quality parameters. 
Table (3) Confidence Interval of Correlation Factors

\begin{tabular}{|c|c|c|c|c|c|c|c|c|c|c|c|c|c|c|c|c|c|c|c|c|}
\hline \multirow[b]{2}{*}{ Interval } & \multicolumn{2}{|c|}{ HCO3 } & \multicolumn{2}{|c|}{$\mathbf{C a}$} & \multicolumn{2}{|c|}{ Cl } & \multicolumn{2}{|c|}{$\mathbf{F e}$} & \multicolumn{2}{|c|}{ T. Har. } & \multicolumn{2}{|c|}{$\mathbf{K}$} & \multicolumn{2}{|c|}{ Mg } & \multicolumn{2}{|c|}{$\mathbf{N a}$} & \multicolumn{2}{|c|}{$\mathrm{NaCl}$} & \multicolumn{2}{|c|}{$\mathrm{SO}_{4}$} \\
\hline & lower & upper & lower & upper & lower & upper & lower & upper & lower & upper & lower & upper & lower & upper & lower & upper & lower & upper & lower & uppe \\
\hline HCO3 & & & -0.482 & 0.758 & -0.833 & 0.31 & -0.824 & 0.335 & -0.286 & 0.841 & -0.675 & 0.602 & -0.149 & 0.878 & -0.566 & 0.704 & -0.832 & 0.312 & -0.948 & -0.28 \\
\hline $\mathbf{C a}$ & -0.482 & 0.758 & & & -0.765 & 0.47 & -0.809 & 0.374 & 0.519 & 0.97 & -0.634 & 0.647 & -0.587 & 0.688 & -0.165 & 0.874 & -0.47 & 0.765 & -0.826 & 0.33 \\
\hline $\mathrm{Cl}$ & -0.833 & 0.31 & -0.765 & 0.47 & & & -0.254 & 0.850 & -0.494 & 0.751 & -0.59 & 0.686 & -0.736 & 0.519 & -0.318 & 0.83 & & & -0.116 & 0.88 \\
\hline $\mathbf{F e}$ & -0.824 & 0.335 & -0.809 & 0.374 & -0.254 & 0.850 & & & -0.752 & 0.493 & -0.782 & 0.435 & -0.581 & 0.693 & -0.355 & 0.816 & -0.249 & 0.852 & 0.224 & 0.94 \\
\hline T. Har. & -0.286 & 0.841 & 0.519 & 0.97 & -0.494 & 0.751 & -0.752 & 0.493 & & & -0.547 & 0.718 & -0.155 & 0.877 & 0.116 & 0.927 & -0.492 & 0.752 & -0.817 & 0.35 \\
\hline $\mathbf{K}$ & -0.675 & 0.602 & -0.634 & 0.647 & -0.59 & 0.686 & -0.782 & 0.435 & -0.547 & 0.718 & & & -0.568 & 0.703 & -0.557 & 0.711 & -0.59 & 0.686 & -0.57 & 0.70 \\
\hline Mg & -0.149 & 0.878 & -0.587 & 0.688 & -0.736 & 0.519 & -0.581 & 0.693 & -0.155 & 0.877 & -0.568 & 0.703 & & & -0.221 & 0.86 & -0.734 & 0.522 & -0.75 & 0.49 \\
\hline $\mathbf{N a}$ & -0.566 & 0.704 & -0.165 & 0.874 & -0.318 & 0.83 & -0.355 & 0.816 & 0.116 & 0.927 & -0.557 & 0.711 & -0.221 & 0.86 & & & -0.312 & 0.832 & -0.573 & $0.69 \mathrm{~s}$ \\
\hline $\mathrm{NaCl}$ & -0.832 & 0.312 & -0.47 & 0.765 & & & -0.249 & 0.852 & -0.492 & 0.752 & -0.59 & 0.686 & -0.734 & 0.522 & -0.312 & 0.832 & & & -0.116 & 0.88 \\
\hline $\mathrm{SO}_{4}$ & -0.948 & -0.289 & -0.826 & 0.330 & -0.116 & 0.885 & 0.224 & 0.941 & -0.817 & 0.353 & -0.57 & 0.701 & -0.75 & 0.495 & -0.573 & 0.699 & -0.116 & 0.885 & & \\
\hline
\end{tabular}




\section{6- Conclusions}

The conclusions of the present study include that the conventional treatment plant has important effect on the decreasing of the concentrations of iron and sulfate from raw water. One of the important ground water parameters is ion of iron the conventional treatment plant effects on the removal of iron of about 50 percent. On the other hand, conventional treatment effects the removal of sulfate from ground water of about $50 \%$. The conventional treatment plant main process enhances the quality of ground water through increment the concentration of dissolved oxygen to the optimum value. The using of statistics was used to determination of the correlation of treated ground water parameters and it is found that there is a positive correlation for ions of iron and sulfate concentration. The testing of confidence ensures that correlation where the interval of confidence of $95 \%$ is positive ends.

\section{CONFLICT OF INTERESTS.}

- There are no conflicts of interest.

\section{7- References}

[1] Ojo Olumuyiwa I. etal "Groundwater: Characteristics, qualities, pollutions and treatments: An overview", International Journal of Water Resources and Environmental Engineering Vol. 4(6), pp. 162-170, June 2012

[2] Heath Ralph C., "Basic Ground-Water Hydrology, Department of the Interior Donald Paul Hodel", Secretary U .S. Geological Survey Dallas L. Peck, Director, 1987.

[3] Gibb p. James "Water Quality and Treatment of Domestic Groundwater Supplies", Illinois state water survey, Urbana, 1973.

[4] Chilton J., "Groundwater, Water Quality Assessments - A Guide to Use of Biota, Sediments and Water in Environmental Monitoring" - Second Edition Edited by Deborah Chapman (C 1992, 1996 UNESCO/WHO/UNEP.

[5] WHO, "Guidelines for drinking water, recommendations", Geneva: World Health Organization, Vol. 2, 1993.

[6] Hofkes E.H. etal, "Small Community Water Supplies", John Wiley \& Sons, Enlarged Edition, 1983.

[7] Vigneswaram S, etal, "Conventional water treatment technologies water treatment technologies, wastewater recycle, reuse and reclamation", volume II. (www.eoless.net/eoless-sampleallchapter.aspx).

[8] Al-Husseini H.H.E. "Evaluation of shut al-Hilla water quality for domestic use and the suitability of main water treatment plants on it" Msc thesis ,College of Engineering ,University of Babylon ,1999.

[9] Ismail Alhassan H. etal, "Groundwater Quality Assessment in Urban Area of Baghdad, Iraq, Using Multivariate Statistical Techniques", Eng. \&Tech. Journal, Vol.33, Part (A), No.2, 2015.

[10] McGhee, Terence J. "Water supply \& Sewerage" McGraw - hill, Inc., sixth edition -1991.

[11] Loftus, G.R. \& Loftus, E.F. "Essence of Statistics ", (2nd Edition). New York: McGraw Hill, 1988.

[12] Shen David, \& Zaizai Lu," Computation of Correlation Coefficient and Its Confidence Interval in SAS" Paper 170-31, SAS Institute Inc. (www2.sas.com/proceedings/sugi31/170-31). 


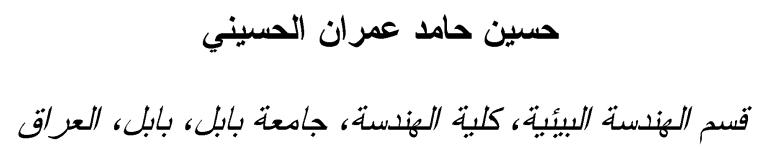

Husseini73@yahoo.com

تزداد اهمية المياه الجوفية كمصدر للمياه العذبة في العديد من الدول. بالاضافة الى ذلك تحتوي العديد من المدن على

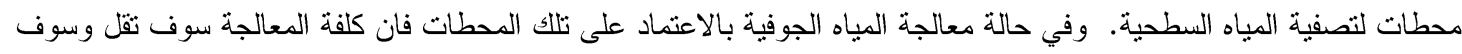
يساعد ذلك على الاعتماد على المياه السطحية والجوفية كمصدر لتجهيز مياه الثرب. في في هذه الدراسة تم دراسة استة امكانية استخدام طرق المعالجة التقليدية في معالجة المياه الجوفية وتم فحص نوعية المياه الجوفية خلال فترة الدراسة. وقد وجد انها ضمن فدن المو اصفات المعتمدة باستثناء عنصر الحديد. و وجد كذلك ان هناك تاثير لوحدات المعالجة في تحسين نوعية مياه الثرب بزئ بزيادة نسبة الاكسجين المذاب باتجاه القيم المنلى. كما وجد ان المحطة كانت فاعلة في ازالة بعض العناصر المهمة الموجودة في المياه الجوفية

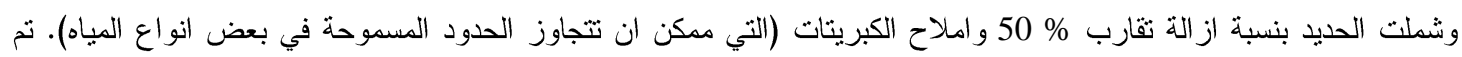

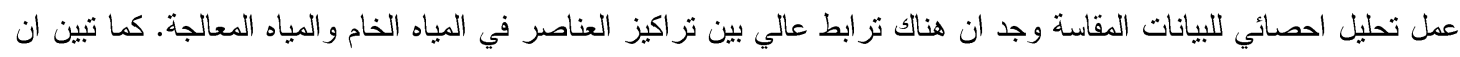
هناك معامل ارتباط مرتفع بين عنصر الحديد وايون الكبريتات في مصفوفة الارتباط. بالاضافة الى ذلك تم تطبيق اختبار مجال

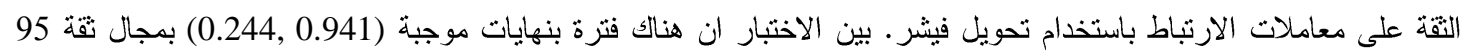
\% لمعامل الارتباط بين عنصري الحديد و الكبريتات. الكلمات الدالة: نوعية المياه، المياه الجوفية، المعالجة التقليدية. التحليل الاحصائي. 